\title{
BIOLUMINESCENCE-BASED ASSAYS FOR ASSESSING ANTIBACTERIAL PROPERTIES OF MEDICINAL PLANTS
}

\author{
N. Kováts and E. Horváth \\ Institute of Environmental Sciences, University of Pannonia \\ H-8200 Veszprém, Egyetem u. 10, Hungary \\ E-mails:kovats@almos.uni-pannon.hu; horvatheszter@almos.uni-pannon.hu
}

(Received 28 January, 2015; Accepted 10 September, 2015)

Extended research has been carried out to clarify the ecological role of plant secondary metabolites (SMs). Although their primary ecological function is self-defence, bioactive compounds have long been used in alternative medicine or in biological control of pests. One single plant may contain a wide variety of bioactive compounds, making analytics rather costly. The total bactericide capacity can be quantified by either microbiological or ecotoxicological methods. Here, the principle and possible applications of a specific bacterial bioluminescence inhibition based ecotoxicological assay are reviewed.

Key words: antibacterial property, bioactivity, bioluminescence, Vibrio fischeri

\section{INTRODUCTION}

Plant secondary metabolites (SMs) were earlier considered by botanists as mere waste products of primary metabolism. It was a German botanist, Ernst Stahl (1888), who was able to show experimentally that these SMs serve as defence compounds. Although the primary ecological function of these SMs is self-defence, antimicrobial compounds have long been used in alternative medicine (reviewed by e.g. Šarić-Kundalić et al. 2011, Shikov et al. 2014). Also, their use as natural pest control is well established (e.g. Burt 2004, Demirci et al. 2008, Vasinauskienè et al. 2006).

One single plant may contain a wide variety of bioactive compounds, making analytics rather costly. The total bactericide capacity can be quantified by either microbiological or ecotoxicological methods. In microbiological assays, which can be classified as diffusion, dilution or bioautographic methods (reviewed by Rios et al. 1988), generally inhibitory effect (growth inhibition) 
on one single selected bacterial strain is assessed. Similarly, ecotoxicological tests using bioluminescent bacteria are measuring inhibitory effect, expressed as reduction of bioluminescence.

The light emission in bioluminescent bacteria is closely related to cellular metabolism, and thus its strength depends on the metabolic status of the organism. In toxic environment, the bacterial luciferase could be inhibited resulting in the decrease in the light intensity. The end-point of the test is the reduction of light output, which is proportional to the strength of the toxin (Fig. 1). Toxicity is normally expressed as $\mathrm{EC}_{50}$ value (which is the calculated concentration of toxicant corresponding to the inhibition value of $50 \%$ ).

The test has a widely established use in monitoring diverse environmental media and has proven sensitive for a wide range of toxicants (reviewed by Girotti et al. 2008).

\section{MATERIALS AND METHODS}

\section{Test organisms}

The first luminescent bacterium strain was named by J. F. Heller in 1854 (Ma et al. 2014). Most bioluminescent bacteria are of marine origin, except the freshwater Vibrio qinghaiensis sp. Q67, the freshwater $V$. cholerae and the terrestrial Photorhabdus species. Vibrio fischeri (recently renamed Aliivibrio fischeri)

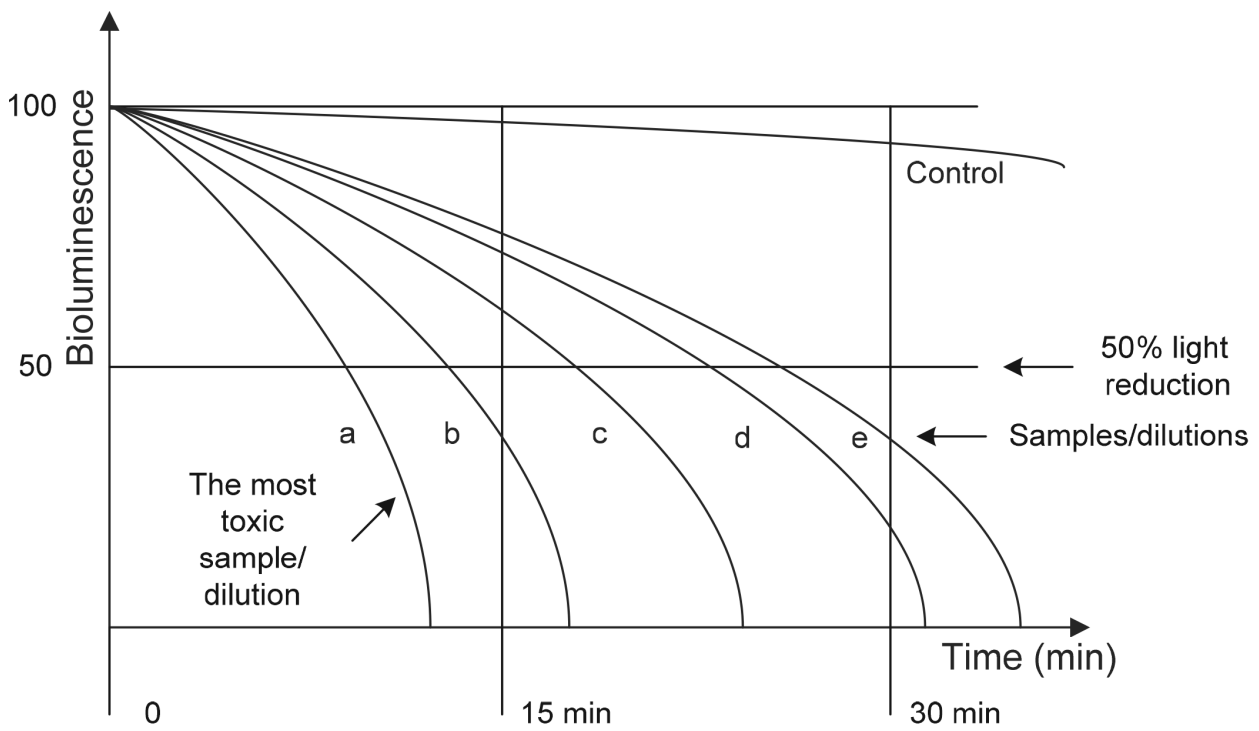

Fig. 1. Luminescence inhibition is roughly proportional to the concentration of the toxic compound 
is the most widely used test organism and also, this species is prescribed by national and international standards. In order to avoid the problem of maintaining salty environment for $V$. fischeri during the test, the employment of $V$. qinghaiensis sp. Q67, a freshwater luminescent bacterium that does not need to maintain a salty environment and has a similar mechanism of light emission, can be an alternative (Ye et al. 2011).

Bioluminescence-based assays often apply recombinant bacteria. Watt et al. (2007) used whole cell Escherichia coli luminescent biosensors to determine the antibacterial actions of 16 herbal tinctures and found the method appropriate to set a range from undetectable to high antibacterial activity. In another study (Chan et al. 2013) two recombinant bacterial biosensors, E. coli HB101_pUCD607_lux and Acinetobacter baylyi ADP1_recA_lux were applied to examine the dose-response relationships and mechanism of action of allyl isothiocyanate (AIT) and cinnamaldehyde (CNAD). Both luminescent bacteria were employed in parallel: RLU (relative luminescence unit) was measured and plate count experiments were carried out.

It should also be noted that Vibrio species are used in traditional microbiological assessments of medicinal herbs with potential antimicrobial property as well, such as V. fischeri (Manilal and Idhayadhulla 2014, Ranjithkumar et al. 2011), V. parahaemolyticus (Manilal and Idhayadhulla 2014, Snoussi et al. 2008, Vijayakumar et al. 2012, Yano et al. 2006), V. mimicus (Manilal and Idhayadhulla 2014), V. alginolyticus (Manilal and Idhayadhulla 2014, Snoussi et al. 2008), V. alcaligenes (Manilal and Idhayadhulla 2014); V. vulnificus (Manilal and Idhayadhulla 2014, Snoussi et al. 2008), V. fluvialis (Snoussi et al. 2008), V. cholerae (Islam et al. 2008, Mahboubi and Haghi 2008) and V. harveyi (Manilal and Idhayadhulla 2014).

\section{Test systems}

The earliest commercial application of this biochemical reaction dates back to 1981, when Beckman Instruments introduced its system, which is presently marketed under the name "Microtox" (Microbics Corporation, Carlsbad, CA, later on AZUR Environmental) (Bulich and Isenberg 1981). This is still the most widely used test system.

Other commercial systems exist, such as ToxAlert (Merck), LUMIStox (Hach Lange), BioTox (ABOATOX). These are compatible with ISO 113483:2007, Water quality - Determination of the inhibitory effect of water samples on the light emission of Vibrio fischeri (Luminescent bacteria test).

Campisi et al. (2005) reported that colour of the sample might cause a significant decrease of light output due to physical effects, creating the potential for false-positives. In order to avoid this source of error, Lappalainen et 
al. $(1999,2001)$ developed a kinetic test system (ABOATOX Ascent Luminometer, referred shortly as Flash system). This test was later standardised (ISO 21338:2010: Water quality - Kinetic determination of the inhibitory effects of sediment, other solids and coloured samples on the light emission of Vibrio fischeri (kinetic luminescent bacteria test)).

\section{DISCUSSION}

\section{Applications}

Conforti et al. (2008) were the first to apply the Microtox system to determine toxicity of a wide range of herbal infusions and decoctions, including Borago officinalis L., Foeniculum vulgare Miller subsp. piperitum (Ucria) Cout., Malva sylvestris L., and Mentha aquatica L. In their test, only the bioluminescence inhibition of the concentrated extract was measured. It was reported that none of the extracts reached the toxic threshold ( $20 \%$ of effect).

Skotti et al. (2014) screened the total phenolic content, the antioxidant activity and toxicity of some Greek medicinal herbs (Melissa officinalis L., Origanum vulgare L., Origanum dictamnus L., Salvia officinalis L. and Hyssopus officinalis L.) and found that bioluminescence inhibition of the two Origanum species exceeded the $20 \%$ of toxicity threshold. In general, toxicity of plant extracts did not correlate to their total phenolic content and antioxidant activity.

In both studies, the bioluminescence inhibition test was used as a measure of acute systemic toxicity and extrapolation to human health risk was made. Conforti et al. (2008) concluded that as the extracts did not reach the toxic level, they pose an irrelevant toxicity for the human health; Skotti et al. (2014) calculated that even those plants, which were proven toxic, are consumed in such quantity, which can be considered safe. Fort (1992) found that for the purpose of monitoring toxins in pharmaceuticals, Microtox ECx values could be correlated with the LD values from assays using mouse survival; however, we have to stress, that results of a bacterial ecotoxicological assay should not be used for human health risk extrapolation.

On the other hand, the test can be used as a measure of the antibacterial capacity of the given sample: similarly to standard microbiological protocols, a bacterium is used as a test species, only the measured end-point differs (bioluminescence inhibition instead of growth inhibition). As such, the method has been used for screening within different plant families, such as: Lamiaceae (Kováts et al. 2011), Asteraceae (Kováts et al. 2010), Umbelliferae (Kováts, unpublished data), Malvaceae (Kováts, unpublished data) and Boraginaceae (Kováts, unpublished data). In most cases, traditional use of the selected herbs showed a good correlation with bioactivity expressed as bioluminescence inhibition. 
Essential oils of different Tanacetum chemotypes were screened using the Vibrio fischeri bioassay to detect antibacterial activity: two chemotypes of Tanacetum parthenium (L.) Schultz Bip. (Polatoğlu et al. 2010a); different parts of a new T. argyrophyllum chemotype (Polatoğlu et al. 2010b) and two new T. chiliophyllum (Fisch. et Mey.) Schultz Bip. var. chiliophyllum chemotypes (Polatoğlu et al. 2012). In all three studies, ecotoxicity was compared to microbiological methods. In case of Tanacetum parthenium and T. argyrophyllum higher response was observed in the $V$. fischeri assay in comparison to microbial tests.

While the visible (measurable) end-point of the test is the reduction of light output, Chan et al. (2013) in a study using bioluminescent recombinant bacteria demonstrated that the tested compounds (allyl isothiocyanate and cinnamaldehyde) damaged cell membranes, and also disrupted cellular metabolism and energy production in bacteria.

Potential further use can be the detection of quorum sensing activity of some medicinal plants. Bioluminescence of $V$. fischeri is based on quorum sensing: a minimal population density is required for triggering light emission. It has been experimentally proven that terrestrial plants traditionally used as medicines may also produce anti-QS compounds (Adonozio et al. 2006). These anti-QS compounds can be of great interest in the treatment of bacterial infections. As such, this test can provide additional information in comparison to standard microbiological procedures.

\section{REFERENCES}

Adonizio, A. L., Downum, K., Bennett, B. C. and Mathee, K. (2006): Anti-quorum sensing activity of medicinal plants in southern Florida. - J. Ethnopharmacol. 105: 427-435. http://dx.doi.org/10.1016/j.jep.2005.11.025

Bulich, A. A. and Isenberg, D. L. (1981): Use of the luminescent bacterial system for the rapid assessment of aquatic toxicity. - ISA Transactions 20: 29-33.

Burt, S. (2004): Essential oils: their antibacterial properties and potential applications in foods: a review. - Int. J. Food Microbiol. 94: 223-253. http://dx.doi.org/10.1016/j.ijfoodmicro.2004.03.022

Campisi, T., Abbondanzi, F., Casado-Martinez, C., DelValls, T. A., Guerra, R. and Iacondini, A. (2005): Effects of sediment turbidity and color on light output measurements for Microtox Basic Solid-PhaseTest. - Chemosphere 60: 9-15. http://dx.doi.org/10.1016/j. chemosphere.2004.12.052

Chan, A. C., Ager, D. and Thompson, I. P. (2013): Resolving the mechanism of bacterial inhibition by plant secondary metabolites employing a combination of whole-cell biosensors. - J. Microbiol. Meth. 93: 209-217. http://dx.doi.org/10.1016/j.mimet.2013.03.021

Conforti, F., Ioele, G., Statti, G. A., Marrelli, M., Ragno, G. and Menichini, F. (2008): Antiproliferative activity against human tumor cell lines and toxicity test on Mediterranean dietary plants. - Food Chem. Toxicol. 46: 3325-3332. http://dx.doi.org/10.1016/j. fct.2008.08.004 
Demirci, F., Guven, K., Demirci, B., Dadandi, M. Y. and Baser, K. H. C. (2008): Antibacterial activity of two Phlomis essential oils against food pathogens. - Food Control 19: 1159-1164. http://dx.doi.org/10.1016/j.foodcont.2008.01.001

Fort, F. (1992): Correlation of Microtox EC, with Mouse LD. - In Vitro Toxicol. 5: 73-82.

Girotti, S., Ferri, E. N., Fumo, M. G. and Maiolini, E. (2008): Monitoring of environmental pollutants by bioluminescent bacteria. - Anal. Chim. Acta 608: 2-29. http://dx.doi. org/10.1016/j.aca.2007.12.008

Islam, M. J., Barua, S., Das, S., Khan, M. S. and Ahmed, A. (2008): Antibacterial activity of some indigenous medicinal plants. - J. Soil Nat. 2(3): 26-28.

ISO 11348-3:2007, Water quality - Determination of the inhibitory effect of water samples on the light emission of Vibrio fischeri (Luminescent bacteria test).

ISO 21338:2010, Water quality - Kinetic determination of the inhibitory effects of sediment, other solids and coloured samples on the light emission of Vibrio fischeri (kinetic luminescent bacteria test).

Kováts, N., Ács, A., Gölöncsér, F. and Barabás, A. (2011): Quantifying of bactericide properties of medicinal plants. - Plant Sign. Behavior 6(6): 777-779. http://dx.doi.org/10.4161/ psb.6.6.15356

Kováts, N., Gölöncsér, F., Ács, A. and Refaey, M. (2010): Quantification of the antibacterial properties of Artemisia absinthium, A. vulgaris, Chrysanthemum leucanthemum and Achillea millefolium using the Vibrio fischeri bacterial bioassay. - Acta Bot. Hung. 52(1-2): 137-144. http://dx.doi.org/10.1556/ABot.52.2010.1-2.e2

Lappalainen, J., Juvonen, R., Nurmi, J. and Karp, M. (2001): Automated color correction method for Vibrio fischeri toxicity test. Comparison of standard and kinetic assays. Chemosphere 45: 635-641. http://dx.doi.org/10.1016/s0045-6535(00)00579-8

Lappalainen, J., Juvonen, R., Vaajasaari, K. and Karp, M. (1999): A new flash method for measuring the toxicity of solid and colored samples. - Chemosphere 38: 1069-1083. http://dx.doi.org/10.1016/s0045-6535(98)00352-x

Ma, X. Y., Wang, X. C., Ngo, H. H., Guo, W., Wu, M. N. and Wang, N. (2014): Bioassay based luminescent bacteria: interferences, improvements, and applications. - Sci. Total Environ. 468-469: 1-11. http://dx.doi.org/10.1016/j.scitotenv.2013.08.028

Mahboubi, M. and Haghi, G. (2008): Antimicrobial activity and chemical composition of Mentha pulegium L. essential oil. - J. Ethnopharmacol. 119: 325-327. http://dx.doi. org/10.1016/j.jep.2008.07.023

Manilal, A. and Idhayadhulla, A. (2014): Potential in vitro antimicrobial efficacy of Holigarna arnottiana (Hook. f.). - Asian Pac. J. Trop. Biomed. 4(1): 25-29. http://dx.doi. org/10.1016/s2221-1691(14)60203-3

Polatoğlu, K., Demirci, F., Demirci, B., Gören, N. and Başer, K. H. C. (2010a): Antibacterial activity and the variation of Tanacetum parthenium (L.) Schultz Bip. essential oils from Turkey. - J. Oleo Sci. 59(4): 177-184. http://dx.doi.org/10.5650/jos.59.177

Polatoğlu, K., Demirci, F., Demirci, B., Gören, N. and Başer, K. H. C. (2010b): Antimicrobial activity and essential oil composition of a new T. argyrophyllum (C. Koch) Tzvel var. argyrophyllum chemotype. - J. Oleo Sci. 59(6): 307-313. http://dx.doi.org/10.5650/ jos.59.307

Polatoğlu, K., Demirci, B., Demirci, F., Gören, N. and Başer, K. H. C. (2012): Biological activity and essential oil composition of two new Tanacetum chiliophyllum (Fisch. et Mey.) Schultz Bip. var. chiliophyllum chemotypes from Turkey. - Ind. Crop. Prod. 39: 97-105. http://dx.doi.org/10.1016/j.indcrop.2012.02.005 
Ranjithkumar, J., Sivasankari, K. and Sekar, T. (2011): Screening of antimicrobial activities of an indigenous herb Cassia occidentalis. - Elixir Appl. Bot. 39: 4584-4588.

Rios, J. L., Recio, M. C. and Villar, A. (1988): Screening methods for natural antimicrobial products with antimicrobial activity: a review of the literature. - J. Ethnopharmacol. 23: 127-149. http://dx.doi.org/10.1016/0378-8741(88)90001-3

Šarić-Kundalić, B., Dobeš, C., Klatte-Asselmeyer, V. and Saukel, J. (2011): Ethnobotanical survey of traditionally used plants in human therapy of east, north and northeast Bosnia and Herzegovina. - J. Ethnopharmacol. 133: 1051-1076. http://dx.doi. org/10.1016/j.jep.2010.11.033

Shikov, A. N., Pozharitskaya, O. N., Makarov, V. G., Wagner, H., Verpoorte, R. and Heinrich, M. (2014): Medicinal plants of the Russian Pharmacopoeia; their history and applications. - J. Ethnopharmacol. 154: 481-536. http://dx.doi.org/10.1016/j.jep.2014.04.007

Skotti, E., Anastasaki, E., Kanellou, G., Polissiou, M. and Tarantilis, P. A. (2014): Total phenolic content, antioxidant activity and toxicity of aqueous extracts from selected Greek medicinal and aromatic plants. - Ind. Crop. Prod. 53: 46-54. http://dx.doi. org/10.1016/j.indcrop.2013.12.013

Snoussi, M., Hajlaoui, H., Noumi, E., Usai, D., Sechi, L. A., Zanetti, S. and Bakhrouf, A. (2008): In-vitro anti-Vibrio spp. activity and chemical composition of some Tunisian aromatic plants. - World J. Microbiol. Biotechnol. 24: 3071-3076. http://dx.doi. org/10.1007/s11274-008-9848-6

Stahl, E. (1888): Pflanzen und Schnecken. - Jenaische Zeitschr. f. Naturwiss. 22: 557-684.

Vasinauskienè, M., Radušienè, J., Zitikaitè, I. and Survilienė, E. (2006): Antibacterial activities of essential oils from aromatic and medicinal plants against growth of phytopathogenic bacteria. - Agron. Res. 4: 437-440.

Vijayakumar, A., Duraipandiyan, V., Jeyaraj, B., Agastian, P., Raj, M. K. and Ignacimuthu, S. (2012): Phytochemical analysis and in vitro antimicrobial activity of Illicium griffithii Hook. f. et Thoms extracts. - Asian Pac. J. Trop. Dis. 2(3): 190-199. http://dx.doi. org/10.1016/s2222-1808(12)60045-0

Watt, K., Christofi, N. and Young, R. (2007): The detection of antibacterial actions of whole herb tinctures using luminescent Escherichia coli. - Phytother. Res. 21: 1193-1199. http://dx.doi.org/10.1002/ptr.2238

Yano, Y., Satomi, M. and Oikawa, H. (2006): Antimicrobial effect of spices and herbs on Vibrio parahaemolyticus. - Int. J. Food Microbiol. 111(1): 6-11. http://dx.doi.org/10.1016/j. ijfoodmicro.2006.04.031

Ye, Z., Zhao, Q., Zhang, M. and Gao, Y. (2011): Acute toxicity evaluation of explosive wastewater by bacterial bioluminescence assays using a freshwater luminescent bacterium, Vibrio qinghaiensis sp. nov. - J. Hazard. Mater. 186: 1351-1354. http://dx.doi. org/10.1016/j.jhazmat.2010.12.013 